\title{
Milestones in Fruit and Vegetable Production, Processing, and Quality
}

\author{
Justin R. Morris ${ }^{1}$ and Pamela L. Brady \\ Institute of Food Science and Engineering, University of Arkansas, 2650 N. Young Ave., Fayetteville, AR 72704
}

The produce industry has seen tremendous change and growth in the past 100 years as a result of increased domestic production, technological improvements in harvesting and processing, and greater availability, diversity, and quality of products (Fig.1). Minimally processed fruit and vegetables as well as an ever-increasing number of processed items have with added convenience and safety to our produce. Processed products have gained widespread acceptance because they not only offer the convenience of quick and easy preparation, but also are comparable, and in some cases superior to, fresh forms in quality and nutritional value (Sammonds, 2000)

In 1999-2000, Americans consumed $296 \mathrm{lb}$ of vegetables and 276 $\mathrm{lb}$ of fruit per capita (Kaufman et al., 2000). Processed product made up over half of all vegetables and fruit consumed, with most of the processed fruit (43\%) in the form of juice.

Quality indicates a product's suitability for a particular use and is an important characteristic of fruit and vegetables. Cook (2001) found that quality characteristics are the most important determinants when consumers are deciding to purchase fruit and vegetables. Quality encompasses sensory properties (appearance, texture, and flavor), nutritive value, chemical constituents, mechanical properties, functional properties, and freedom from defects (Abbott, 1999), and depends upon the cultivar, preharvest cultural practices and climatic conditions, maturity at harvest, and harvesting method (Kader, 2002). Handling procedures, conditions at harvest, and time between harvesting and marketing or processing also affect final product quality.

The production and maintenance of high quality have been the fundamental goals of the fruit and vegetable industry throughout the 20th century. Preparation and processing practices as well as advances in quality control and evaluation to provide safe healthful food for human nutrition have evolved with technology and consumer demands over the past century.

\section{PRODUCTION PRACTICES}

Many production practices have come about as diversified, small farms have given way to speciality farms (Ware and McCollum, 1968). Early in the 20th century, a typical farmer might have produced fruit and vegetables for family use and sold the excess to local markets (Fig. 2 ). As the century progressed, many farmers became more specialized, growing only one or two crops for sale. Sometimes farmer cooperatives specializing in a given crop emerged. Researchers directed much attention toward developing equipment and cultural practices to accommodate fruit and vegetable producers. Fundamental to this evolution in production practices were developments in mechanized harvesting and plant breeding/biotechnology.

HaRVEST MEChanization. Specialized production and large-scale operations created harvesting problems that have led to new harvest methods. Securing and supervising manual labor for harvesting presented problems (Corbett et al., 1926), and with the increased distances to markets, the necessity for care in product handling increased. In order to assure appropriate care in handling perishable products, some growers in the 1920s adopted a quality-quantity basis for paying harvest crews, that is, wages depended both on the quantity of produce picked and on its freedom from harvest injury.

Finding adequate labor for harvesting fruit and vegetables in the United States ceased to be a problem during the Depression (Morris, 1990), and hand harvesting remained common thoughout the 1930s

Appreciation is expressed to Martha Davis, Department of Crop, Soil, and Environmental Science and Jan Blevins, Institute of Food Science and Engineering for their assistance in reviewing and revising this manuscript.

${ }^{1}$ To whom reprint requests should be addressed; e-mail jumorris@uark.edu.
(Fig. 3). However, during World War II, a major harvest labor crisis occurred that stimulated our modern movement toward mechanization of fruit and vegetable harvesting for the processing market. The labor shortages resurfaced during the Korean conflict. During recent times, migrant workers have solved much of the harvest labor shortage but have created new societal issues. When the influx of migrant workers began neither the employers nor the government were concerned for their welfare. Both the government and society became increasingly concerned about the problems of the migrant worker in the 1960s and 1970s and implemented major improvements and expenditures in wages, housing, education, and health benefits. All of these developments increased the cost of fruit and vegetable harvesting and made mechanization of the fruit and vegetable industry for the processing market necessary. One attempt to mechanize cane fruit production was the focus of research at the University of Arkansas. These efforts produced an efficient, integrated production system that, with minor adaptations for species, has been used

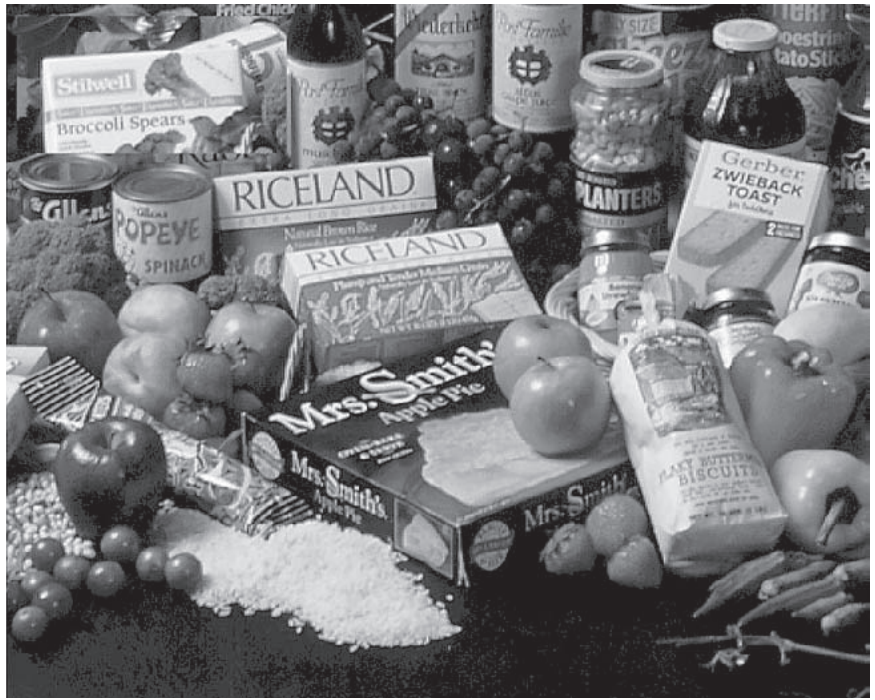

Fig. 1. During the past 100 years, fresh and processed fruits and vegetables have assumed a major role in the diets of Americans. In 2001, over $500 \mathrm{lb}$ of produce per capita were consumed. Photo: IFSE, University of Arkansas.

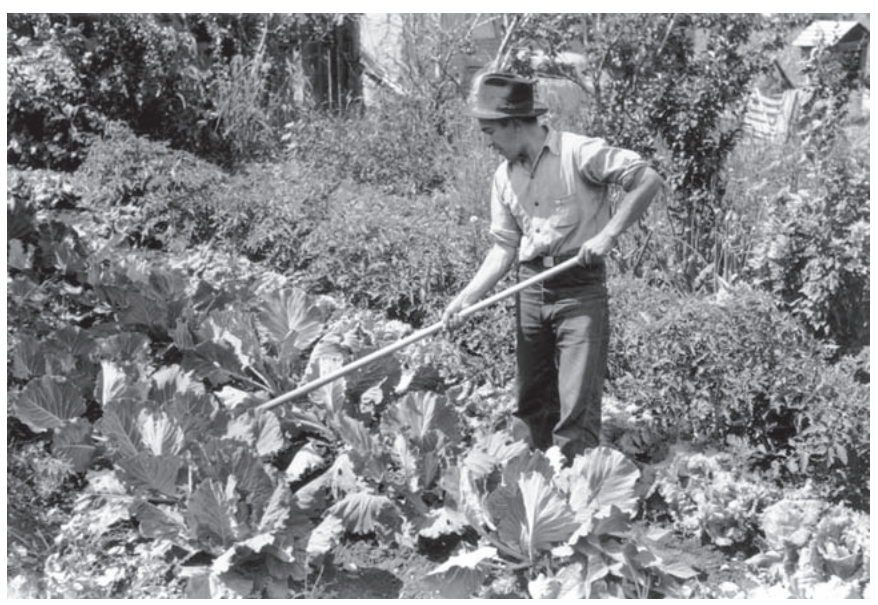

Fig. 2. During the first half of the 20th century, many families obtained their fruits and vegetables by gardening. However, the wide selection of products available in the markets led to greater use of purchased produce in the latter part of the century. Photo: USDA Photo Center. 


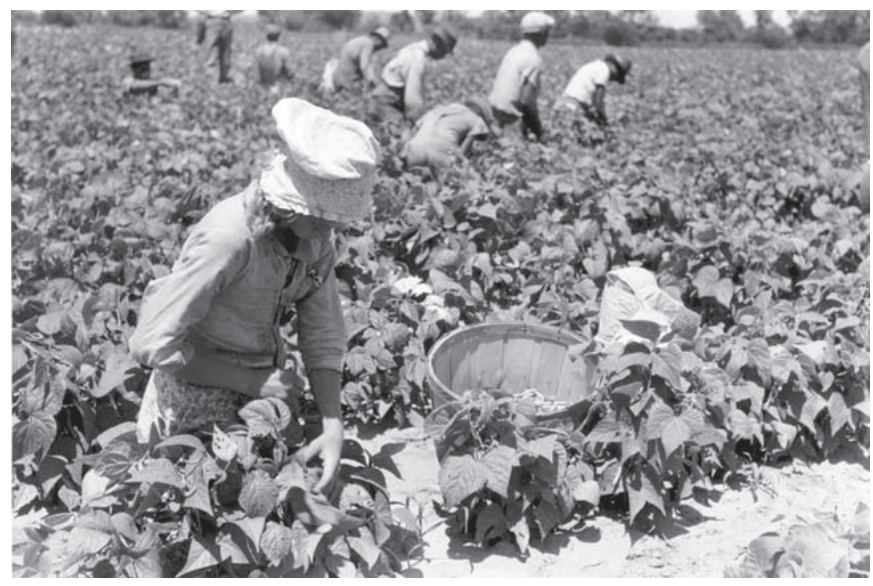

Fig. 3. Hand harvesting of beans was common in 1939 but labor shortages due to World War II would lead to movement toward mechanical harvesting. Photo: USDA Photo Center.

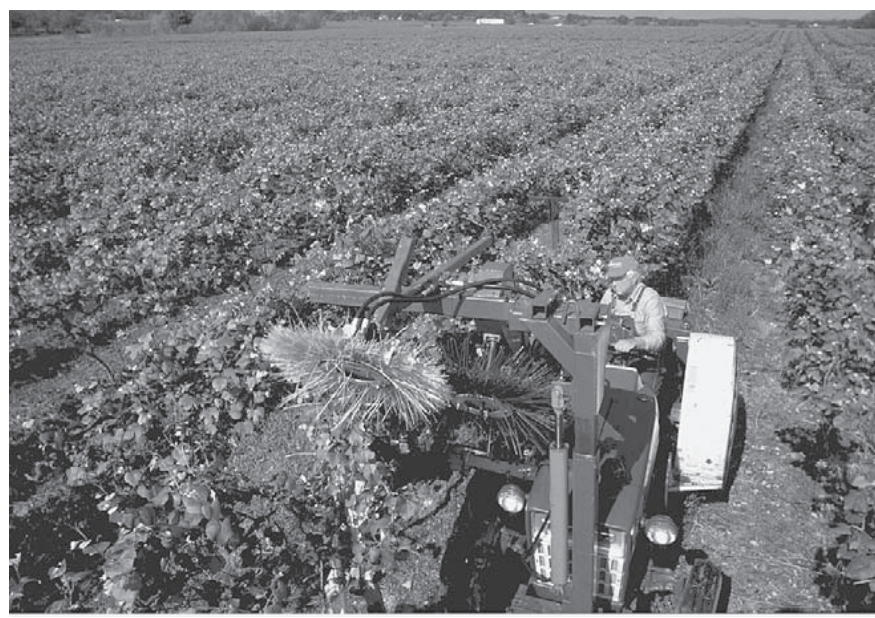

Fig. 4. The University of Arkansas holds a patent on a system for complete vineyard mechanization that uses over 40 machines and/or attachments to allow mechanization of the 12 most common trellising systems in the grapeproducing regions of the world. Photo: IFSE, University of Arkansas.

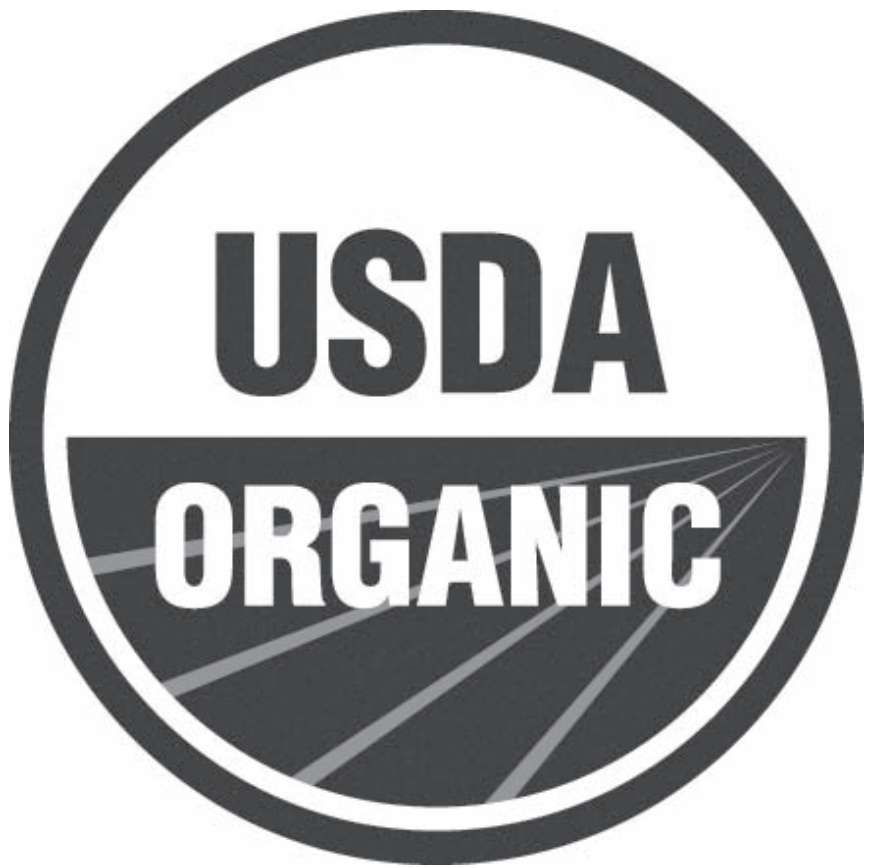

Fig. 5. The USDA Organic label assures consumers that produce is produced and handled according to NOP guidelines. to pick erect blackberries, black raspberries, red raspberries, trellised blackberries, and gooseberries (Morris et al., 1978).

Major developments in juice and wine grape harvest mechanization occurred in the early and mid-1960s (Morris, 1990), and mechanization was practiced commercially in this industry by the late 1960s. Mechanically harvested grapes can have better quality than hand-harvested grapes when delivered promptly to a processing unit (Whittenberger et al., 1971). In 2002 the University of Arkansas patented a system for complete vineyard mechanization. This system uses over 40 machines and/or attachments (Fig. 4) that allow for mechanization of the 12 most common trellising systems in the grape-producing regions of the world (Morris, 2002).

In general, mechanical harvesting of vegetables preceded mechanical harvesting of fruit (Morris, 1990). Sweet corn for processing has been harvested mechanically since the late 1940s. Plant breeders developed cultivars with concentrated ripening and resistance to damage. Mechanical harvesting systems also have been developed for snap beans, southern peas, lima beans, cucumbers, peas, beets, dry beans, cabbage, carrots, onions, potatoes, tomatoes, spinach, and sweetpotatoes. Research on mechanical harvesting of tree fruit started in the 1950s in California with cling peaches for processing (Morris, 1990). Since that time, mechanical harvesting systems have been developed for apricots, cherries, cranberries, olives, prunes, and sweet cherries.

The tomato processing industry in California is an excellent example of successful harvest mechanization. In anticipation of future labor shortages, researchers at UC Davis began breeding tomatoes suitable for mechanical harvesting in 1950 (Thompson and Blank, 2000). Engineers began work on equipment for this operation at the same time. Commercial use of the new variety and the harvester began in 1962. When the Bracero program for the exportation of agricultural workers from Mexico to the United States ended in 1964, causing a major reduction in the labor supply, about $25 \%$ of the crop was harvested mechanically. By 1968, $95 \%$ of California's tomato crop was mechanically harvested.

Mechanization has proven extremely useful in harvesting many types of produce for processing; although most fresh market produce is still hand harvested (Morris, 2002). Research efforts are underway to refine mechanical harvesting systems. Harvesting by machine for processing may improve quality over that obtained through hand harvesting because of the faster rate of harvesting and the reduced holding time in the field before processing. However, for some products, the once-over nature of mechanical harvesting results in lower quality than more selective hand harvesting. The greatest success in harvest mechanization has occurred with totally integrated systems that include proper cultivars, cultural programs, harvesting principles, postharvest handling, and product utilization.

Plant bReeding and biotechnology. As mechanical harvesting developed and markets extended beyond local areas, growers learned that not all varieties can be transported, stored, marketed, and processed successfully. Within each commodity, a tremendous range of cultivars can differ in composition, quality, and postharvest life (Kader, 2002). Modern plant breeding and biotechnology techniques have resulted in genetic manipulations leading to the development of cultivars to meet the diverse needs of processors, retailers, and consumers. Examples include tomato and carrot cultivars with higher carotenoids and Vitamin A content, sweet corn cultivars that maintain their sweetness longer after harvest, cantaloupe cultivars with higher sugar content and firmer flesh, and produce resistant to damage in shipment and handling.

Altering characteristics of crop plants through breeding and genetic engineering have improved yields and quality of fruit and vegetables as well as increased plant hardiness and pest resistance. The impact these technologies will have on society will depend largely upon how well they are accepted by producers and consumers (CAST Biotechnology Task Force, 2003). Questions about food allergens, germplasm diversity, and food safety arise as the result of this technological change. Inherent in the successful development and adoption of new and emerging biotechnologies for agriculture is the need to increase public understanding of the associated scientific, economic, legislative, environmental, and societal issues.

ORGANIC PRODUCTION. With advances in breeding and biotechnology came increased use of inorganic chemicals for pest control and fertilization, with a concomitant increase in concern for social and environmental 
preservation and safety. A segment of producers and consumers continues to advocate organic production without plant modification through genetic engineering. Organic production of fruit and vegetables has been practiced in the United States since the late 1940s. During the 1990s organic farming became one of the fastest growing segments of U.S. agriculture (NOP, 2003). Organic farming systems rely on ecologically based practices, such as cultural and biological pest management, and virtually exclude the use of synthetic chemicals.

U.S. producers are turning to organic farming systems as a potential method for lowering input costs, decreasing reliance on nonrenewable resources, satisfying consumer demands, and capturing high-value

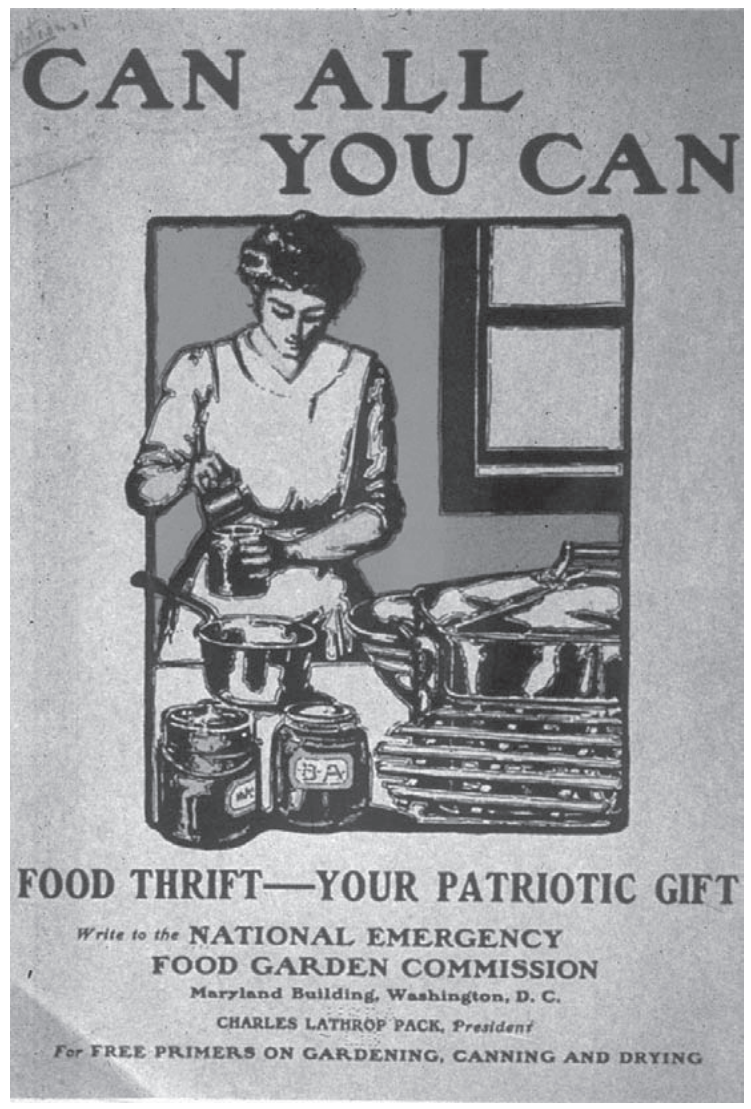

Fig. 6. Resurgence of interest in home canning occurred during World War II when a large proportion of commercially processed produce was required for military use. Photo: USDA Photo Center.

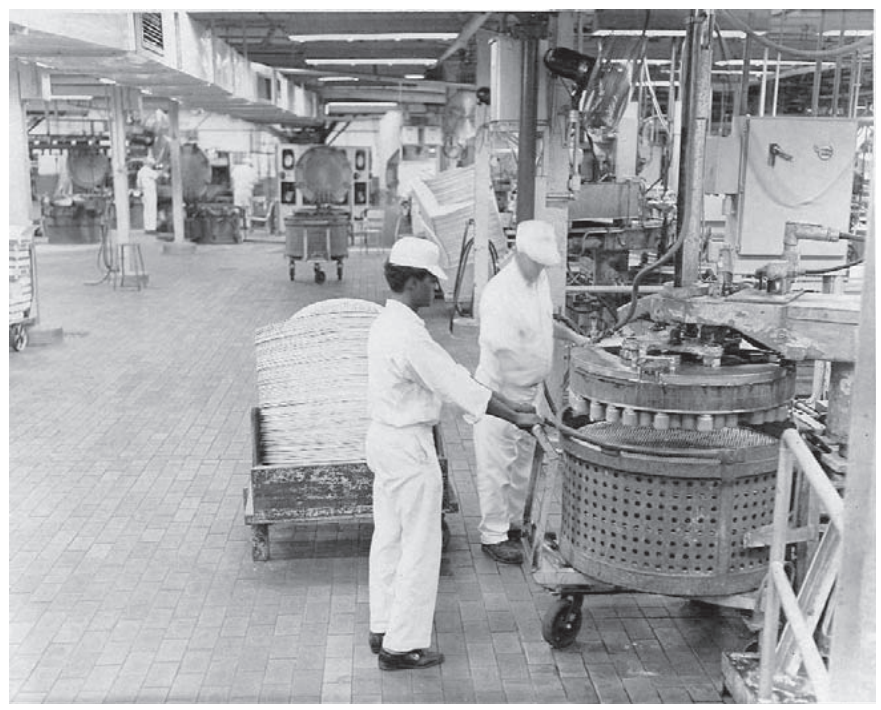

Fig. 7. Over the past 100 years, developments in processing procedures and equipment have changed the appearance of food processing plants. Photo: Gerber Foods, Ft. Smith, Ark. markets at premium prices to boost farm income. Food manufacturers have developed processed organic products. Once a niche product sold in a limited number of retail outlets, the $\$ 7.8$ billion U.S. organic food market now includes a wide variety of venues including farmers' markets, natural product supermarkets, conventional supermarkets, and club stores (Dimitri and Greene, 2002).

The growth in the organic market has stimulated a need for verification that products are indeed produced according to certain standards. Thus, the organic certification industry evolved. By the late 1980s, after an attempt to develop a consensus of production and certification standards, the organic industry petitioned Congress to draft the Organic Foods Production Act (OFPA) to define organic. The OFPA and the National Organic Program (NOP), which went into effect in October 2002, contain regulations that were developed to ensure that organically labeled products meet consistent national standards. Any producer or handling operation that sells agricultural products bearing the organic label (Fig. 5) must adhere to NOP standards. The labeling requirements of the new program apply to raw, fresh products and processed foods that contain organic ingredients.

\section{PROCESSING PRACTICES}

Along with developments in production systems have come parallel advancements in processing. Preservation of fruit and vegetables for use when fresh produce was not readily available has always been important. Until the early 1900s home preservation was limited to processes like curing, drying, and pickling. Home canning became more prevalent in the early 1900 s with the invention of the pressure cooker, but improved procedures for commercial drying, canning, freezing, and other preservation technologies during the 1900 s led to a decline in home preservation activities.

DRYING. Probably the oldest form of food preservation is drying. It involves the removal of water so that it is unavailable for use by spoilage organisms. Between 1898 and 1921, sun drying became a prominent industry due to its simplicity and relatively inexpensive equipment requirements (Corbett et al.,1926). This industry was most highly developed in California where there was an abundance of raw material for drying and the climate offered opportunities for developing this industry. However, in the mid-1920s poor weather during the drying season resulted in significant crop losses and led to increased interest in artificial methods of dehydrating. Since about 1960, a great deal of effort has gone into developing high quality dehydrated products (Somogyi and Luh, 1986). Among the factors studied are improvement of plant cultivars to better adapt them to drying, new processing technologies, better quality control procedures, lower moisture in the finished product, and better packaging.

CANNING. In 1914 the U.S. Department of Agriculture (USDA) began the Extension Service. Its mission was to offer outreach information to consumers on topics related to farming and homemaking skills. Guidance on home and community canning activities were foundations of early Extension activities.

The increased popularity, availability, and quality of commercially canned products in the 1920s and 1930s resulted in decreased consumer interest in home canning. However, shortages during the war years of the 1940s revitalized interest in home gardening and home canning activities (Fig. 6). Although home canning declined for most of the latter part of the 20 th century, a moderate resurgence occurred in the 1990s. This renewed interest was associated with the Gulf War, the predicted Millennium computer problems raising fears of new food shortages, and consumers wanting to assume control over the composition of their foods.

Commercial canning of fruit and vegetables began in the late 1800s. Major accomplishments during this period were the invention of steam retorts and the development of tin containers to package processed product (Denny, 2001). During the early 20th century, small processing plants were built and operated by individuals or groups of growers as a means of using both excess product from fresh markets and produce that did not meet the standards of appearance and quality required for these markets (Corbett et al., 1926). Many of these processing operations failed because the material available for processing often represented a number of cultivars with varying character that made it impossible to produce uniform, standardized products. 


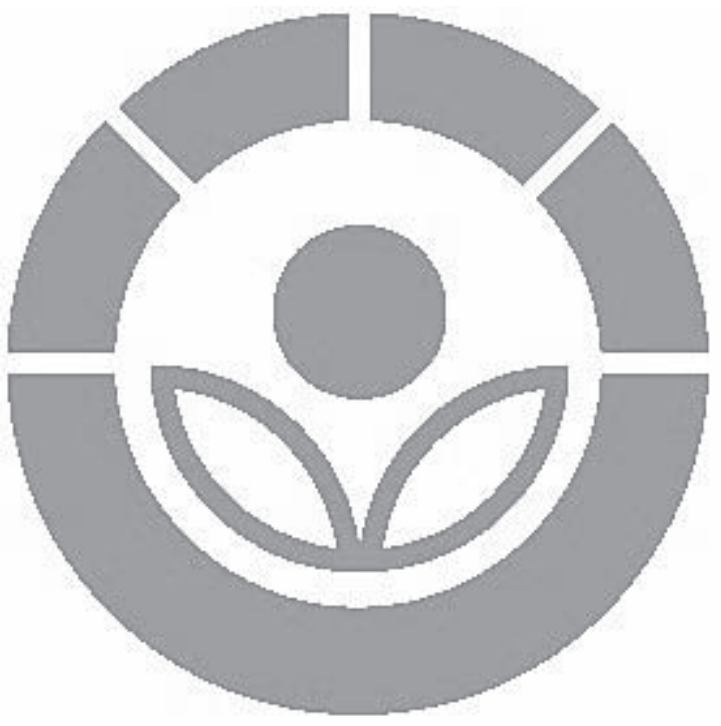

Fig. 8. The radura symbol is required on all produces receiving ionizing radiation.

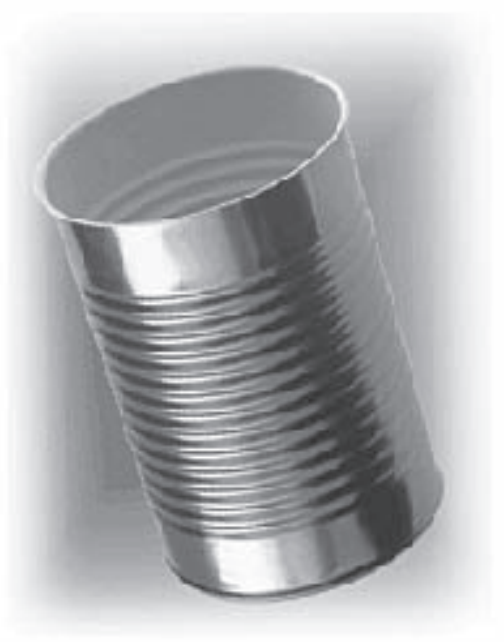

Fig. 9. Modern cans are often made of tinplate, a thin sheet of steel covered with a very fine layer of tin to protect the steel from the effects of the environment and keep it bright and shiny. Photo: Ball Corporation.

The National Canners Association (NCA, now known as the National Food Processors Association) was established in 1907 and began supporting research in 1910 (Woodroof, 1986). Their industrial laboratory, organized in 1913, was responsible for much of the research leading to advances in the science and technology of canning. In 1917, W.D. Bigelow of NCA conceived the idea of using thermocouples to measure the temperature in the interior of pressure kettles and cans of food to determine the heat distribution. Thermocouple measurements have become the basis for our present day knowledge of time-temperature processes for canning food (Goldblith, 1972). C. Olin Ball, an NCA researcher, combined the heat penetration and thermal resistance studies of NCA scientists to develop a method that helped canners establish processing parameters for different sizes of cans and various foods. These findings helped reduce fears of botulinum contamination from canned products and overcame a major hurtle in establishing consumer acceptance of processed fruit and vegetables.

During the 1930s, 1940s and 1950s new inventions brought greater success, new capabilities, and more competition to the canning market. An almost endless variety of foods was available year round. A new type of labor force emerged to work the production lines. Conveyor belts and automatic machinery such as washers and fillers moved the products through at astonishing rates.

Commercial sterilization methods and equipment for processing fruit and vegetables have been developed since the early 1950s (Woodroof, 1986). Vertical and horizontal still retorts have been replaced by continuous methods of sterilization. Round-the-clock processes have replaced batch operations. Advantages of these developments have included: improved, more consistent product quality, higher plant capacity, continuous plant operation, fewer package failures, and lower expenditures for steam, cooling water, and labor (Fig.7). Major disadvantages of these developments have been the high costs for equipment, especially for smaller processors, and short seasonal operation.

In the United States large-scale commercial juice production did not begin until after 1925 (Shear, 1961). Before that, the only unfermented juice in the United States was the Concord grape juice that Welch began bottling in 1869 in Vineland, NJ. Although cider had been consumed since colonial times, commercial production of canned and bottled apple juice did not begin until the 1930s. A major milestone in the juice processing industry was the introduction of frozen concentrated orange juice during the 1940s. This product not only significantly increased the amount of orange juice used but also was a major contributor to consumer acceptance of frozen fruit and vegetables.

Freezing. Freezing has been used as a food preservation method for centuries, though the quality of early frozen produce generally was poor. Crude attempts to freeze fruit for commercial use were made in the early 1920s, but many attribute the rise of the frozen food industry to Clarence Birdseye. A major development by Birdseye was a method for quick freezing foods released in 1923 (NFRA, n.d.). In the 1930s he developed strategies for marketing these frozen products to the public.

Improved product quality, better packaging, and the ability to transport produce via refrigerated trucks resulted in the industry taking greater advantage of freezing as a processing method. During the 1950s frozen food sales exceeded $\$ 1$ billion. Primary frozen food sales were fruit and vegetables purchased by the foodservice industry (AFFI, 2000). Consumer use of frozen foods jumped when the TV dinner was introduced. This product offered a complete meal in frozen form including an entree/meat item, a starch, a vegetable, and sometimes a dessert. With the 1960 s came the introduction of the microwave oven for home use. TV dinners were replaced by frozen entrees. By the end of the 20th century, the variety of frozen foods grew rapidly with choices such as upscale dinners, ethnic favorites, breakfast selections, foods designed for special dietary needs, and those targeted to specific consumer audiences (such as kid meals).

IRRADIATION. The use of ionizing radiation to extend the shelf life of fruit and vegetables has predominantly focused on radiation's ability to alter rates of ripening and control postharvest pathogens (Thayer and Rajkowski, 1999). Early studies did not look at control of human pathogens, but they did provide data on the doses that various products could tolerate and on the doses necessary to inactivate plant pathogens. Studies are currently underway in several countries to look at the effectiveness of ionizing radiation as a means of eliminating human pathogens in fresh fruit and vegetables, fresh cut produce, fruit juices, sprouts, and seeds (Clark, 2002). Irradiation or combination treatments of radiation with processes like chlorination seem promising for reducing pathogens without the undesirable quality changes that often accompany more traditional processes such as heat treatments.

Because irradiation does not significantly alter the appearance of fruit and vegetables, consumers have been concerned that they would be unable to identify irradiated products. This concern has been addressed by the requirement that all irradiated produce be labeled with the radura symbol (Fig. 8).

Fresh-CUT PRODUCE. Minimal processing has been one of the hottest trends in produce marketing in the last decade. Fresh cut produce, defined as "any fruit or vegetable or combination thereof that has been physically altered from its original form, but remains in a fresh state," offers the flavor, nutritional value, and freshness of fresh produce along with added convenience (Kader, 2002).

Attempts to develop fresh cut produce began in the 1940s. However, major advances in the process occurred during the 1970s when the foodservice industry began to demand prepared produce to reduce in-store preparation costs. Companies like McDonalds and other fast food chains led to a thriving market for shredded lettuce and chopped onion.

As more women joined the workforce in the 1980s, speed and convenience of preparation became a primary consideration for foods used in the home. Cut and packaged produce provided these characteristics, but 
at that time there were still issues related to inconsistent quality and shelf life in the marketplace. A leading challenge for processors was to stop the produce from turning brown. Processors found they had to start with a better quality product, handle it gently during processing, and package it appropriately to reduce the development of the off-colors (Fig. 11). Other technological advances that have improved the quality of freshcut products include advanced air-drying techniques to reduce moisture damage to the cut product, better refrigeration, enhanced sanitation and the application of Hazard Analysis Critical Control Point (HACCP) procedures in processing and retailing operations.

\section{PACKAGING}

Whether produce is processed by drying, canning, freezing, or irradiation, appropriate packaging is essential to assure a high quality product. Enormous progress in packaging has been made since the earliest days of the produce processing industry, and progress continues to be made today.

GLASs. Glass jars have long been the packaging medium of choice for home canners who lack the equipment to close metal cans. In 1914 Ball Glass began making rubber sealing rings for jars (Ball Corporation, 1998). These were nearly replaced when the company introduced two-piece jar closures made of zinc and glass in 1930. These closures were later replaced by closures of tinplate and glass and eventually by all tinplate lids and rings. Although glass is still the favored packaging for home canners, it has been replaced largely by lighter weight, less breakable materials for commercial use.

Cans. Canning began in the early 1800 s (CMI, n.d.). Originally cans were made of iron sheets dipped into molten tin. By the mid 1800s, iron was replaced by steel, a far superior material that could be rolled out into thin sheets. In the 1930s, electroplating began to replace hot dipping as the way to apply the tin, and today all "tinplate" for cans is made this way. Tinplate is nontoxic, safe, and strong and can be transported, stored, and stacked easily, withstanding the knocks that a can is likely to receive during its journey to the customer.

For most of the 20th century, food cans have been made using three separate pieces of tinplate (Fig. 9). Another type of can emerged in 1964. This can consists of a body and base that are formed from a single disc of tinplate punched into the desired shape. There is no side seam on this can and the bottom is not separate from the sides. Today, nearly all drinks cans and most pet food cans are of this type. The development of an easy-open end for these two-piece cans has led to their use for singleserving packaging of fruit and vegetables and many processors are moving toward using them for all processed fruit and vegetables.

During World War II most metal in the United States was channeled into wartime uses and was unavailable for canning foods except those destined for troops. This focused attention on the development of other types of packaging materials. Fruit and vegetables frozen in paperboard cartons increased in popularity during this period as did dried fruit of all types.

PLastics. Plastics of various types became part of the food packaging scene over the course of the 1900s. Cellulose acetate was first derived from wood pulp in 1900 and developed for photographic uses in 1909 (Hook and Heimlich, n.d.). Although DuPont manufactured cellophane in New York in 1924, it was not commercially used for food packaging until the late 1950s and early 1960s.

The Polyethylene Terephthalate (PET) container entered the market in 1977 for use with beverages. PET is more impermeable than other low-cost plastics making it a popular material for bottles for fizzy drinks, since carbonation tends to attack other plastics, and for acidic drinks such as fruit or vegetable juices. By 1980, foods and other hot-fill products such as jams could also be packaged in PET. Research at the University of Arkansas has demonstrated the feasibility of packaging pickled produce in PET jars (R. Buescher, personal communication).

Since 1980 there has been an enormous increase in the demand for fresh and minimally processed fruit and vegetables. This has required the industry to develop new and improved methods for maintaining quality and extending shelf life of these products (IFT/FDA Task Force, 2001). One packaging technology that has had success is modified atmosphere packaging (MAP). This technique involves either actively or passively controlling or modifying the atmosphere surrounding the product within a package made of various types and/or combinations of films (Fig. 10). One of the first applications of this technology for fresh-cut produce in North America was introduced by the McDonald's fast food chain (Brody 1995), which used MAP of lettuce in bulk-sized packages to distribute the product to retail outlets.

ASEPTIC PACKAGING. The aseptic packaging industry developed in the 1940s (Lofton, 2002). Originally packaging for aseptic products was boxes made of multiple layers of laminates such as paperboard, plastic films, and aluminum foil. In recent years, PET bottles have become common since they are capable of handling carbonated drinks (Clark, 2003).

Aseptic systems offer products that are room temperature shelf stable by filling a sterilized package with a sterile food product within the confines of a hygienic environment. Since aseptically processed liquid foods and beverages are sterilized outside the packaging using an ultra high temperature then cooled before filling packages, time and temperature of the process can be adapted to ensure safety while placing the least thermal stress on the product. This reduces damage to nutrients, especially important in fruit juices where nutrients may be added at extra expense to support health-related claims (Clark, 2003).

A major motivation for aseptic processing and packaging is that the packaging is lighter in weight than that used for hot filling or retort processing (Clark, 2003) and is more environmentally friendly than metal cans. Lower weight containers also save on shipping and are popular with consumers.

Most products available today in retail and food service aseptic packaging are liquid-based foods and beverages such as juice, nectars, milk, and soy-based drinks (Lofton, 2002). Current technology allows aseptic packaging of high acid foods with pieces that are half-inch deep, such as chopped tomatoes. Research is currently underway to develop processes for low-acid particulates.

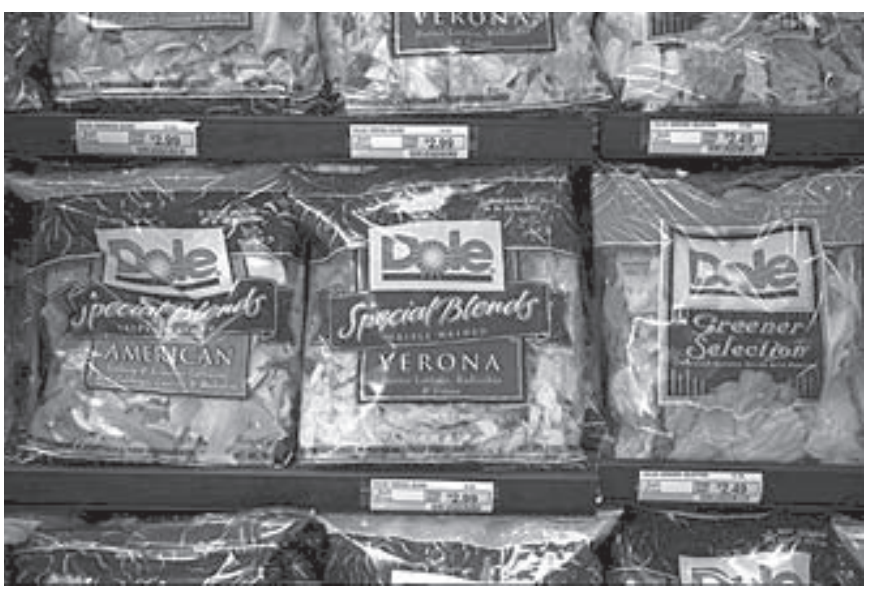

Fig. 10. MAP has allowed the development of a wide variety of fresh, high quality products. Photo: USDA Photo Center.

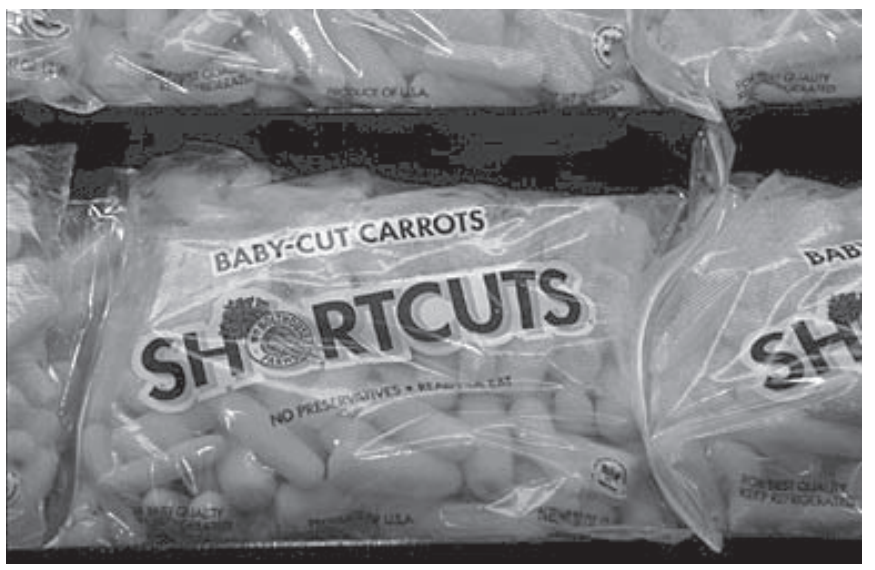

Fig. 11. Fresh cut is the fastest growing segment of the produce industry offering quality and convenience for consumers and the foodservice industry. Photo: USDA Photo Center. 


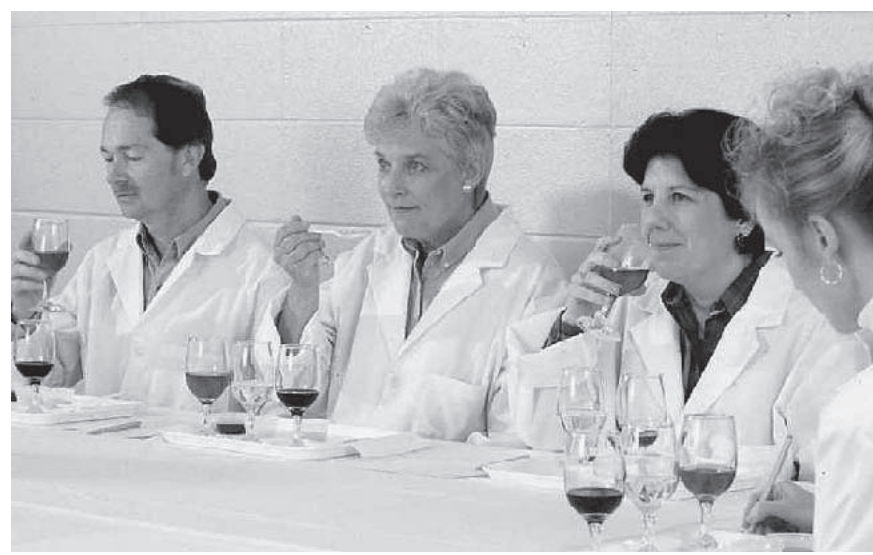

Fig. 12. Modern descriptive panels have the ability to precisely describe food products in terms of their appearance, aroma, flavor, and texture. Photo: IFSE, University of Arkansas.

\section{QUALITY CONTROL AND EVALUATION}

The many advances in produce production, processing, and packaging have led to changes in the final products. Assurance that these advances were having a positive effect on the quality of fruit and vegetables and communication about product quality to prospective users have been on-going challenges for the produce industry. The need for common terminology for quality led to the first U.S. grade standard for produce in 1917 (AMS, n.d.). To enforce these standards, the U.S. Inspection Service for fresh fruit and vegetables was established that same year. The application of federal standards not only promoted grading and standardization of fruit and vegetables in different states but also led to uniform standards in different parts of the country which were shipping to the same market (Corbett et al., 1926). Although the original inspection service was applied at the point of receipt of the produce, it was expanded in 1922 to include inspection at shipping points (AMS, n.d.). Shipping point and receiving point inspections of the same carloads of fruit or vegetables were valuable since they contributed to the knowledge of what happens to produce during transit and to greater research efforts to eliminate transit-related problems.

In 1928, the USDA Agricultural Marketing Service (AMS) began issuing grade standards for processed fruit and vegetables, and in 1930 the Perishable Agricultural Commodities Act was signed prohibiting unfair and fraudulent practices in interstate marketing of fruit and vegetables (AMS, n.d.). In 1946, the Agricultural Marketing Act became law, providing for integrated administration of marketing programs, a scientific approach to marketing problems, and a basic authority for major AMS functions including federal standards, grading and inspection services, market news services, and consumer education.

In the 1990s Fruit and Vegetable Programs of the AMS created two programs specifically addressing quality evaluation of produce. The Qualified Through Verification (QTV) as a voluntary user-fee service was introduced as a pilot program in January 1996. Under QTV, AMS technical specialists work with company management at processing and packing facilities to develop a credible hazard analysis critical control point (HACCP) plan for the facility. This program was developed at the request of the fresh-cut industry. Partners In Quality (PIQ) is a documented quality assurance system patterned after the International Standards Organization's ISO-9000 standards and process control principles and analysis techniques. UnderPIQ, individual packing houses must continually demonstrate and document their ability to pack product that meets all requirements of Federal and State laws and of their customers.

Quality control, defined by van Reeuwijk (1998) as operational techniques and activities that are used to satisfy quality requirements, is critical at all levels of the produce production, processing, and distribution chain. Quality has been generally assessed by the senses (Kramer and Twigg, 1970); however, instrumental measurements of quality characteristics now are often preferred because they reduce variations among individuals, can provide a common language, and have improved legal standing (Abbott, 1999). Instrumental methods of quality evaluation generally measure chemical constituents or physical properties of the commodity that can be related to functional behavior or sensory acceptability.

During the 1940s and through the mid 1950s, instrumental measures of a number of quality attributes were developed and have become rather sophisticated. Today, quality evaluation may include destructive or nondestructive measurements of color, texture, flavor, and nutritional value (Abbott, 1999). Color can be measured with a colorimeter. Several instruments using puncture, compression, deformation, or shearing methods can assess texture. Volatile aroma compounds are analyzed by gas chromatography. Chemical analysis, gas chromatography, or highperformance liquid chromatography determines nutritional values. Internal defects can be detected nondestructively by a light transmittance method or nuclear magnetic resonance imaging technique. Sensory taste panels usually judge flavor.

In all quality measurements, the ultimate judge is still humans who use their senses in deciding whether or not to consume the product. The 20th century saw the development of sensory evaluation as a science (Stone and Sidel, 1993). During the 1940s and 1950s sensory science was advanced through the efforts of the U.S. Army Quartermaster Food and Container Institute. Within the food industry, an expert such as a winemaker, brewmaster, or coffee or tea taster frequently performed early sensory evaluation. These experts still maintain a role in certain segments of the modern industry. However, in many areas, individual judgements have been replaced by groups of evaluators. This began with the development of product cuttings, an informal panel comparison of canned products, in the 1950s, and developed into more formal taste panels in the 1960s and early 1970s, and descriptive analysis panels in the latter part of the 20th century (Fig. 12).

\section{SAFETY OF FRUIT AND VEGETABLES}

People not only want their food to be palatable but also safe and nutritious. Many experts have argued that safety is one of the most important components of quality since a lack of safety can result in serious injury or even death for the consumer. Food safety has been defined as the assurance that the product will not cause harm to the consumer when it is prepared and/or eaten according to its intended use (FAO/WHO, 1997). Safety can be difficult to observe. A product can appear to be of high quality (e.g., well colored, appetizing, flavorful) and yet be unsafe because it is contaminated with pathogenic organisms, toxic chemicals, or physical hazards. On the other hand, a product that seems to lack many of the observable quality attributes can be safe.

Some of the earliest questions related to produce safety date back to the work of Harvey Wiley, Head of the Bureau of Chemistry in the USDA during the early 1900s (IFT, 2000). Wiley questioned the safety of adulterants used in processed foods. Included in the list of adulterated products he and his team investigated were canned vegetables. From 1910 to 1950 , safety research with fruit and vegetables centered primarily on bacteriological spoilage. As people became more reliant on foods processed by commercial processors, researchers focused their efforts on assuring the safety and nutritional value of these foods.

Since 1959, consumer concerns about the safety of fresh fruit and vegetables have focused primarily on issues of chemical contamination. This trend began when the Secretary of Health, Education, and Welfare announced that the FDA had found that part of the cranberry crop might have been contaminated with the weed killer aminotriazole (Lieberman and Kwon, 1998). The announcement, which came just a few days before Thanksgiving, caused major consumer concern (Fig. 13). Although growers and the government responded quickly, minimizing losses in sales, the episode laid the groundwork for future consumer concerns about produce safety.

Safety of produce became a prominent issue again in 1989 with the publication of the Natural Resources Defense Council report Intolerable Risk: Pesticides in Our Children's Food and the airing of the conclusions from this report on the television show "60 Minutes" (Lieberman and Kwon, 1998). These reports claimed that the growth regulator Alar, which was at the time being phased out from use in apple production, posed a significant cancer risk for children. Although the basis for these allegations were seriously flawed, the publicity created a major panic among parents who immediately removed apples from their children's diets. Ultimately the allegations resulted in an estimated \$250 million loss to apple growers and $\$ 125$ million loss to processors of apple products. In 


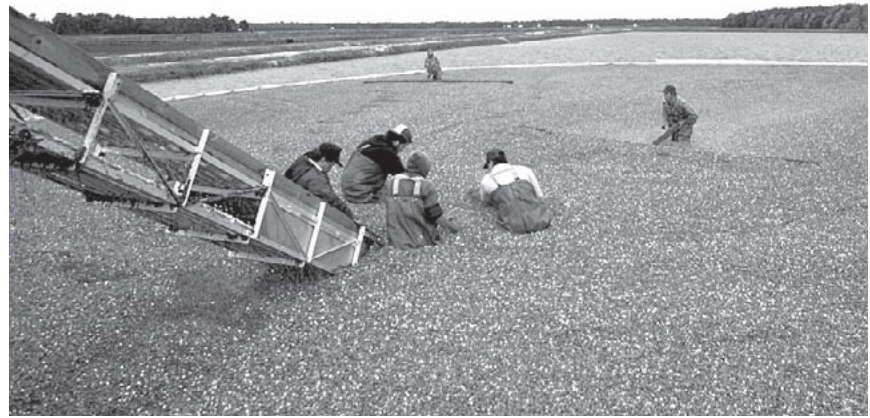

Fig. 13. Produce contamination with farm chemicals became an issue in 1959 when questions were raised about the safety of cranberries. Photo: USDA Photo Center.

addition to the financial losses, consumer confidence in produce safety was eroded severely, and they questioned the steps being taken by government agencies, producers, and processors to assure this safety.

Although consumers have been predominantly concerned about chemical contamination of produce, food safety experts generally agree that microbial contamination is a greater concern because fruit and vegetables are typically the only foods eaten with minimal heating or other treatments to eliminate contaminants. Foodborne illness outbreaks that have been traced to produce include contamination of melons, tomatoes, bean sprouts and orange juice with Salmonella, apple cider and apple juice with Escherichia coli, strawberries with hepatitis A, cucumbers and lettuce with Campylobacter, bean sprouts and iceburg lettuce with Escherichia coli 0157:H7 and raspberries with the protozoan parasite Cyclospora (Beuchat, 1998). Since these organisms are commonly of fecal origin, likely sources of fruit contamination are untreated animal manure and sewage, poor sanitary facilities for workers, poor worker hygiene, and contaminated water. Water quality may be especially important in the produce industry since it is used in the field for irrigation and spraying and in such postharvest operations as washing, conveying, dipping, and icing.

The FDA and USDA (1998) issued the publication Guidance to Industry-Guide to Minimize Microbial Food Safety Hazards for Fresh Fruit and Vegetables in October, 1998. This guide contains recommendations for Good Agricultural Practices (GAPs) and Good Manufacturing Practices (GMPs) to assure the safety of fresh produce. The FDA/USDA guide, while not regulation, has formed the basis for training to assure the safety of fresh produce for producers, handlers, and retailers, both domestically and in countries exporting produce to the United States. A manual to be used in train-the-trainer courses on implementing GAPs and GMPs in countries exporting produce to the United States was prepared under the auspices of the Joint Institute of Food Safety and Applied Nutrition (JIFSAN) and is available online in both English and Spanish at the JIFSAN web site (IFSE/FAO Center, 2002).

\section{ROLE OF PRODUCE IN HUMAN NUTRITION}

The role of fruit and vegetables in helping maintain health was recognized as far back as 1796 when the British Navy began having sailors consume lemon juice to prevent scurvy. However, it was not until the 20th century that science defined the contributions of fruit and vegetables to human health. The first USDA tables of food composition, published in the late 1800 s, provided data on protein, fat, carbohydrate, ash, and fuel (USDA, 2000). The focus of dietary recommendations at the time was for getting appropriate levels of calories, then called fuel (Fig. 14).

From 1912-1924 the relationships between accessory food factors (vitamins) and dietary deficiency syndromes, such as scurvy, pellagra, rickets, and beriberi, were identified. Once diseases resulting from deficiencies were eliminated, the role of diet in the control of chronic disease became a focus of nutritional research, and during the latter part of the 20th century, the focus of nutrition shifted from healthy eating to using food to treat health conditions (Sloan, 1999). Extensive work has been directed toward identifying and describing the role diet plays in preventing and managing such chronic diseases as heart disease, cancer, obesity, and diabetes.

The USDA began issuing Food Guides in 1916 to offer consumers recommendations on food choices. Throughout the many variations in these guides, fruit and vegetables have remained a key component of dietary recommendations. In 1992 the USDA released the Food Guide Pyramid shown in Fig. 15. The pyramid was intended to help Americans make dietary choices that would maintain good health and reduce the risk of chronic disease. A 2001 report by the USDA Economic Research Service indicated that, while the eating patterns of Americans have improved, the recommendations of the Pyramid are still not being met (ERS, 2001). The report estimated that, in order to meet Pyramid recommendations, fruit consumption would need to more than double and consumption of citrus fruit, melons, and berries would need to rise by $150 \%$. Although consumption of vegetables as a group would have to rise only 10 percent, average diets would have to include more than four times as many dark-green leafy and deep-yellow vegetables, three times as many dry beans, peas, and lentils, and fewer servings of starchy vegetables (mostly potatoes).

The USDA Food Guide Pyramid has been criticized by a number of nutritional scientists because they believe it offers misleading information (Willett and Stampler, 2002). For example, the Pyramid suggests significant reductions in fat consumption based on the fact that saturated fats found in red meat and dairy products raise blood cholesterol, a risk factor for coronary heart disease. It ignores the fact that polyunsaturated fat, found in vegetable oils and some fish, reduces cholesterol. Other areas where the Pyramid is thought to be misleading are its recommendations to consume large amounts of complex carbohydrates and its failure to differentiate between plant and animal protein sources. In light of questions

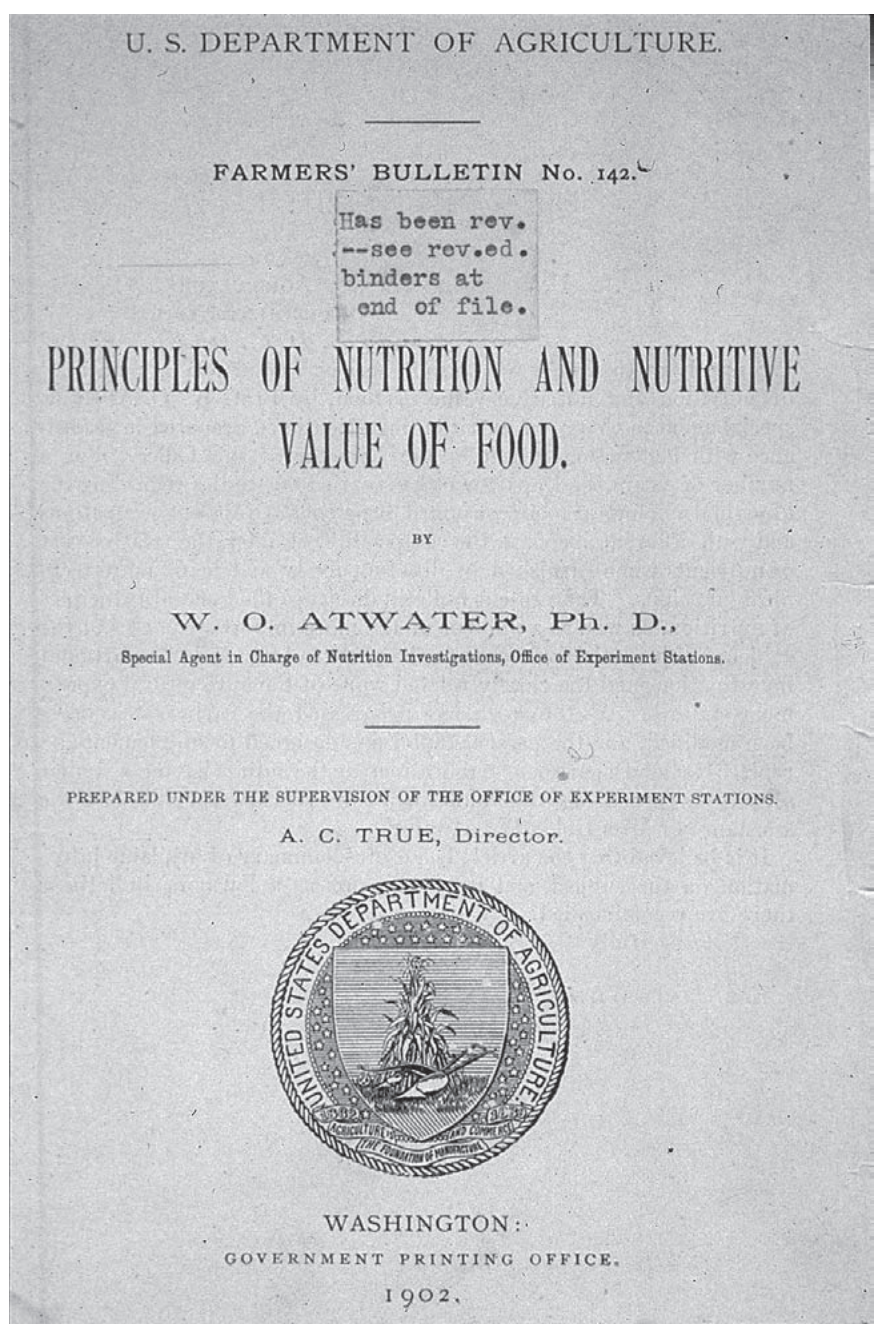

Fig. 14. In 1902, W.O. Atwater, a USDA nutrition pioneer, made dietary recommendations emphasizing the themes of variety, balance, and moderation still being used today. Photo: NAL Historical Archives 


\section{A Guide to Daily Food Choices}

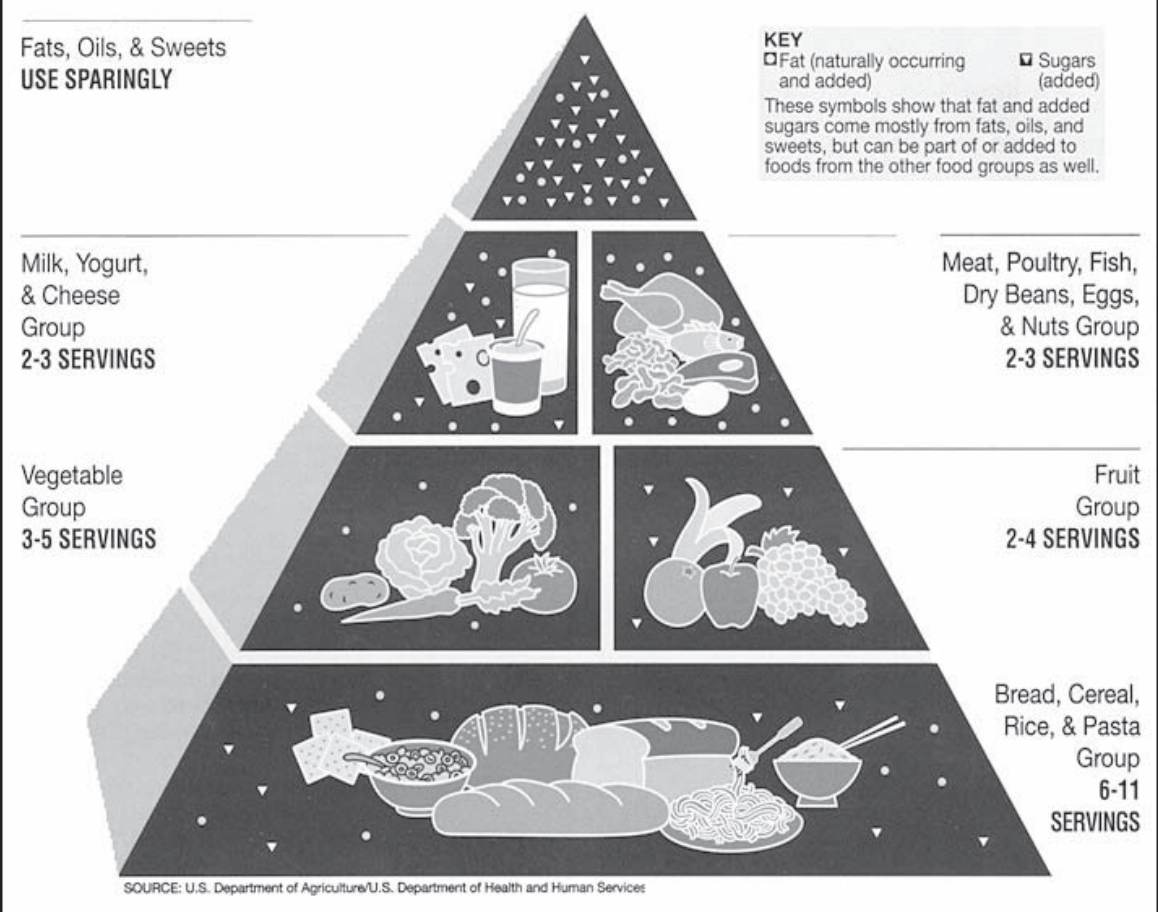

some experts to propose alternative food guidance systems. One such system is a pyramid (Fig. 16) built around the diet traditional to the Mediterranean region (Oldways, n.d.). This diet consists primarily of plant foods, including whole grain breads, pasta, legumes, and fruit and vegetables. Moderate amounts of dairy foods, especially yogurt and cheese, are included each day. Fish and poultry are the main sources of protein, and consumption of these is limited to a few times a week. Daily exercise and wine in moderation are recommended as part of this pyramid's plan. Proponents argue that the plan constitutes an eating pattern actually being followed by people in the Mediterranean area who are known for their long life expectancies. However, critics have argued that it is not the eating pattern traditional for most Americans and that numerous factors in addition to diet may contribute to the longer lives.

Recognition of the contributions produce in the dietcan make to human health has prompted ingredient companies, food manufacturers, and trade associations to search for ways to get more fruit and vegetables, or their healthful components, into the diet (Pszczola, 2003). In 1991, the 5 A Day for Better Health Program was introduced (NCI, 2000), and it has become one of the most widely recognized health promotion programs in the world. The program is the combined efforts of the National Cancer Institute, the Produce for

Fig. 15. Fruit and vegetables are primary components of the USDA's Food Guide Pyramid, which offers guidance for food selection for healthy eating. Photo: Food and Nutrition Center, NAL.

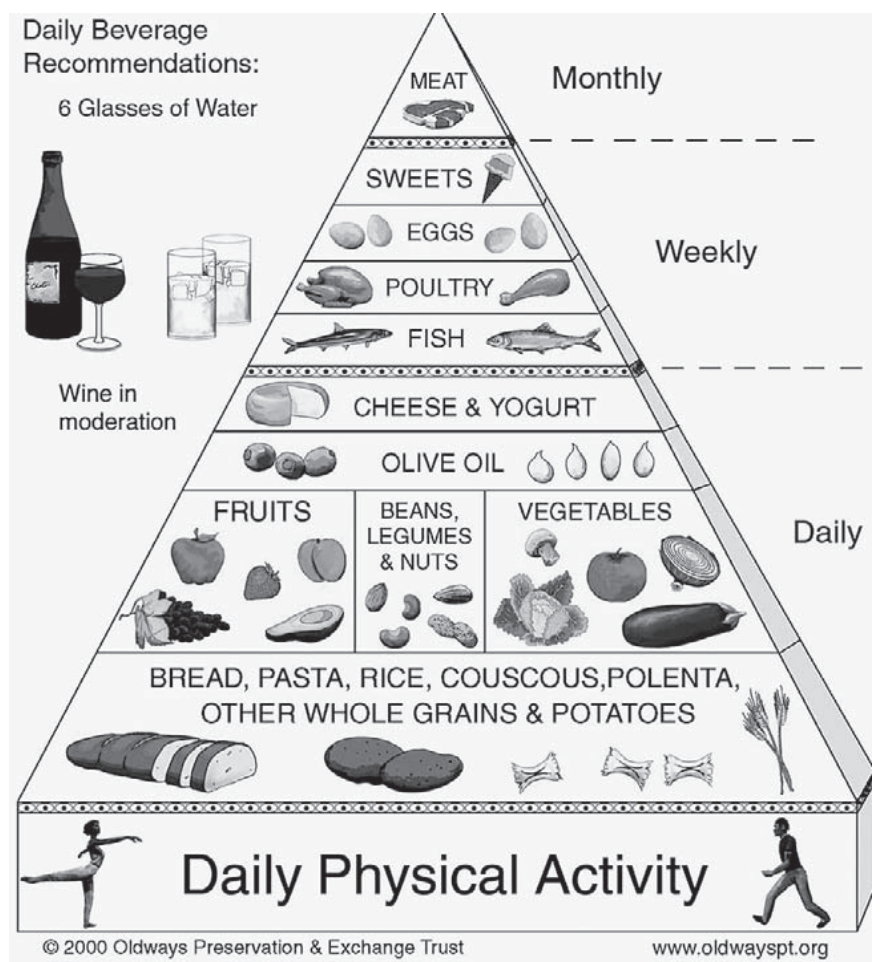

Fig. 16. The traditional Mediterranean diet pyramid with its emphasis on vegetable protein sources and oils has been proposed as an alternative to the USDA pyramid. Photo: Oldways Preservation Trust.

about the appropriateness of the dietary recommendations in the Food Guide Pyramid, the USDA's Center for Nutrition Policy and Promotion has reported that it is currently reassessing the pyramid. This reassessment will be completed in 2004.

Criticisms directed at the USDA's Food Guide Pyramid have led
Better Health Foundation, the American Cancer Society, the Centers for Disease Control and Prevention, the USDA, United Fresh Fruit and Vegetable Association, Produce Marketing Association, and the National Alliance for Nutrition and Activity.

The goal of the National 5 A Day for Better Health Program is to increase the consumption of fruit and vegetables in the United States to 5 to 9 servings every day. In addition, the program seeks to inform Americans that eating fruit and vegetables can improve their health and reduce their risk of cancer and other diseases, including heart disease, hypertension, diabetes, and macular degeneration. The 5 ADay Program also provides consumers with practical and easy ways to incorporate more fruit and vegetables into their daily eating patterns.

Results of the program's efforts have been encouraging (NCI, 2000). The percentage of Americans who know they should eat 5 or more servings of fruit and vegetables a day has increased from 8 to 36 percent since 1991. During the first three years of the program, the average adult's daily consumption of fruit and vegetables increased significantly. Data from the USDA's Continuing Surveys of Food Intakes by Individuals show that from 1989-1991, adults ate an average of 3.9 daily servings of fruit and vegetables. From 1994-1996 that number had increased to approximately 4.6 servings per day, very close to the recommended minimum of five.

In addition to dietary recommendations, other information has evolved for consumers wanting to select foods appropriate for a healthy diet. During the 1900 s food labels became an important means of providing information about the nutritional content of the food. In 1974 the FDA and USDA issued the first nutrition labeling requirements for processed foods (Kurtzweil, 1993). These were revised and expanded in 1991 to mandate nutrition labeling for almost all processed foods regulated by FDA and to authorize appropriate health claims on the labels of such products. Nutrition labeling of fresh fruit and vegetables was voluntary but was encouraged either through information presented at the point of purchase or on take-home literature.

Emerging new ingredient developments may have an influence on health (Pszczola, 2003). For example, components with antioxidant properties are being isolated and concentrated for use in supplements and nutraceutical foods. New cultivars of fruit and vegetables are being developed that are high in healthful components. Fruit and vegetable extracts are being incorporated into a wide range of applications including beverages, snack foods, confections, and dairy products. Combinations of fruit and vegetable concentrates with natural flavors are finding 
increasing uses in such products as frozen novelties. Flavor fractions derived from fruit and vegetables are processed in such a way so as not to lose their nutrient profiles. Fruit and vegetables in combination with other ingredients, such as flax, work synergistically to provide health benefits. Even fruit-derived ingredients, already healthy themselves, are being further enhanced by other nutraceutical ingredients.

\section{CONCLUSION}

The past 100 years have seen tremendous growth in the kinds and amounts of fruit and vegetables available to American consumers. Technological advances in production practices, processing and handling, and packaging and preparation have resulted in products of higher quality and improved nutritional value. This paper has provided a brief overview of a number of the milestones in fruit and vegetable production, processing and quality, though the large number of advances in these areas make it impossible to address them all. The trend toward health-conscious consumers who want high quality foods with little time spent in preparation challenges the fruit and vegetable industry to continue to develop new products and improve the quality, safety, and nutritional value of existing ones.

\section{Literature Cited}

Abbott, J.A. 1999. Quality measurement of fruit and vegetables. Postharv. Biol. Technol. 15:207-225.

AFFI. 2000. History of frozen food. American Frozen Food Institute. 5 Feb. 2003. <www. affi.com/factstat-history.asp>.

AMS. n.d. Fruit and vegetable program factsheets. AMS/USDA. 10 January 2003. <http://www.ams.usda.gov/fv/index.htm>.

Ball Corporation. 1998. Ball corporations natural progression. 3 February 2003. <http://www.ball.com/bhome/images/History_poster.pdf>

Beuchat, L.R. 1998. Surface decontamination of fruit and vegetables eaten raw: A review. World Health Organization. WHO/FSF/FOS/98.2. 2 Feb. 2003 $<$ http://www.who/int/fsf/fos982 1.pdf>.

Brody A. 1995. A perspective on MAP products in North America and western Europe, p. 13-36. In: J.M. Farber and K.L. Dodds (eds.). Principles of modified atmosphere and sous-vide packaging. Technomic, lancsater, Pa.

CAST Biotechnology Task Force. 2003. Biotechnology in animal agriculture: An overview. CAST (Ames, Iowa) Paper 23.

Clark, J.P. 2002. Extending the shelf life of fruit and vegetables. Food Technol. 56(4):98,100,105.

Clark, J.P. 2003. Developments in beverage processing. Food Technol. 57(1): $72-74$.

CMI. n.d. Cans-A visual history. CMI, Wash., D.C. 12 Feb. $2003<$ http://www. cancentral.com/brochure $>$.

Cook, R. 2001. The U.S. fresh produce industry: An industry in transition, p. 27-117. In: A.A. Kader (ed.). Postharvest technology of horticultural crops. Univ. Calif. Div. Agr. Natural Resour. Publ. 3311.

Corbett, L.C., J.S. Caldwell, W. Stuart, W.R. Beattie, and L.B. Flohr. 1926. Horticultural manufactures, p. 601-622. In: Yearbook of Agriculture- 1925. USDA, Wash., D.C.

Denny, C. 2001 (August). The food processing industry: A century of success. NFPA J.

Dimitri, C. and C. Greene. 2002. Recent growth patterns in the U.S. organic foods market. ERS/USDA, Wash., D.C., Agr. Info. Bul. AIB777. 3 Feb. 2003. <http://www.ers.usda.gov/publications/aib777>.

ERS. 2001. Food consumption: Effects of food consumption choices on agriculture. Econ. Res. Serv. Briefing Rm., USDA, Wash., D.C. 3 Feb. 2003. $<$ http://www.ers.usda.gov/briefing/consumption/Effects.htm>.

FAO/WHO. 1997. Codex Alimentarius food hygiene basic texts. Joint FAO/ WHOFood Standards Programme, Codex Alimentarius Commission. Rome, Italy. Pub. \# M-83. 12 Feb. 2003. < http://www.fao.org/docrep/005/y1579e/ y $1579 \mathrm{e} 00 . \mathrm{htm} \#$ Contents $>$.

FDA. 1998. Guidance for industry - Guide to minimize microbial hazards for fresh fruit and vegetables. CFSAN/FDA, Wash., D.C., 31 Jan. 2003. $<$ www.cfsan.fda.gov/ dms/prodguid.html >.

Goldblith, S.A. 1972. Science and technology of thermal processing. Part 2. Food Technol. 26(2):64-69.

Hook, P. and J.E. Heimlich (n.d.). A history of packaging. Ohio State Univ. Fctsht. CDFS-133. 4 Feb. 2003. <http://ohioline.osu.edu/cd-fact/0133.html>.

IFSE/FAO Center. 2002. Improving the safety and quality of fresh fruit and vegetables: A training manual for trainers. Joint Inst. Food Safety and Appl. Nutr., Univ. Md. 15 Feb. 2003. <www.jifsan.umd.edu/gaps.html>.
IFT. 2000. A century of food science. Res. Rpt. Task Force, IFT, Chicago, Ill. IFT/FDA Task Force. 2001.Microbiological safety of controlled and modified atmosphere packaging of fresh and fresh-cut produce. In: Analysis and evaluation of preventive control measures for the control and reduction/elimination of microbial hazards on fresh and fresh-cut produce. FDA/CFSAN, Wash., D.C. 28 Jan. 2003. <http://www.cfsan.fda.gov/ comm/ift3-toc.html>.

Kader, A.A. 2002. Quality parameters of fresh-cut fruit and vegetable products, p. 11-20. In: O. Lamikanra (ed.). Fresh-cut fruit and vegetables-Science, technology, and market. CRC Press, Boca Raton, Fla.

Kaufman, P.R., C.R. Handy, E.W. McLaughlin, K. Park, and G.M.Green. 2000. Understanding the dynamics of produce markets-Consumption and consolidation grow. ERS/USDA, Wash., D.C. Agr. Info. Bul. 758.

Kramer, A. and B.A. Twigg. 1970. Quality control for the food industry. 3rd ed. vol 1. Fundamentals. AVI, Westport, Conn.

Kurtzweil, P. 1993. Good reading for good eating. In: FDA consumer special issue: Focus on food labeling. FDA, Wash., D.C. 28 Feb. 2003. <http: //www.fda.gov/fdac/special/foodlabel/goodread.html>.

Lieberman, A.J. and S.C. Kwon. 1998. Facts versus fears: Areview of the greatest unfounded health scares of recent times. 3rd ed. ACSH, NewYork.

Lofton, J. 2002. The aseptic package-A profile for the future. In Business briefing: Food technology. World Mkt. Res. Ctr. 14 Feb. 2003. <http:// www.wmrc.com/businessbriefing/pdf/foodtech2002/reference/ref19.pdf>.

Morris, J.R., G.S. Nelson, A.A. Kattan, and D.L. Cawthon. 1978. Developing a mechanized harvesting and production system for erect blackberries. HortScience 13(3):228-239.

Morris, J.R. 1990. Fruit and vegetable harvest mechanization. Food Technol. 44(2):97-101.

Morris, J.R. 2002. Vineyard mechanization-A system approach. W. Fruit Grower 122(2):1-2.

NCI. 2000. 5 A Day for Better Health Program evaluation report. NIH/NCI (Bethesda, Md.) Publ. 01-4904.

NFRA. n.d. History of frozen foods: Long and varied. NFRA, Harrisburg, Pa. 25 Jan. 2003. <http://www.nfraweb.org/media/edit1.html>.

NOP. 2003. National Organic Program factsheets. AMS/USDA, Wash., D.C. 28 Jan. 2003. < http:www.ams.usda.gov/nop>.

Oldways. (n.d.) The Mediterranean diet pyramid. Oldways Preservation and Exchange Trust, Boston, Mass. 19 Feb. 2003. <http://www.oldwayspt.org/ pyramids/med/p_med.html>.

Pszczola, D.E. 2003. Getting more fruit and vegetables into foods. Food Technol. 57(1):52-63.

Sammonds, K. 2000. University of Massachusetts nutrient study. CFA, Falls Church, Va. 12 Feb. 2003. <http://www.mealtime.org/alliance/alliance_ umass_study.aspx>.

Shear, S.W. 1961. Historical and economic aspects of the juice industry, p. 1-64. In: D.K. Tressler and M.A. Joslyn (eds.). Fruit and vegetable juice processing technology. AVI, Westport, Conn.

Sloan, A.E. 1999. Top ten trends to watch and work on for the new millennium. Food Technol. 53(8):40.

Somogyi, L.P. and B.S. Luh. 1986. Dehydration of fruit, p. 353-405. In: J.G. Woodroof and B.S. Luh (eds.).Commercial fruit processing. 2nd ed. AVI, Westport, Conn.

Stone, H. and J.L. Sidel. 1993. Historical background. In: Sensory evaluation procedures. 2nd ed. Academic Press, San Diego, Calif.

Thayer, D.W. and K.T. Rajkowski. 1999. Developments in irradiation of fresh fruit and vegetables. Food Technol. 53(11):62-65.

Thompson, J.F. and S.C. Blank. 2000. Harvest mechanization helps agriculture remain competitive. Calif. Agr. 54(3):51-56. 28 Feb. 2003 <http: //danr.ucop.edu/calag/MJ00/pdf/harvest_mech.pdf>.

van Reeuwijk, L.P. 1998. Guidelines for quality management in soil and plant laboratories. FAO (Rome) Publ. M-90. 12 Feb. 2003 <http://www.fao.org/ docrep/w7295e/w7295e00.htm.>.

USDA. 2000. Millennium milestones. In: Agriculture factbook 1999. USDA, Wash.,D.C. 3 Jan. 2003. <http://www.usda.gov/news/pubs/fbook99/sections/ milestones.pdf>.

Ware, G.W. and J.P. McCollum. 1968. The vegetable industry. In: Producing vegetable crops. Interstate Printers \& Publ., Inc. Danville, Ill.

Whittenberger, R.T., D.E. Marshall, J.H. Levin, and B.F. Cargill. 1971. Bulk handling of 'Concord' grapes for processing: Quality evaluation. Annu. Mtg. Amer. Soc. Agr. Eng., St. Joseph, Mich.

Willett, W.C. and M.J. Stampler. 2002. Rebuilding the food pyramid. ScientificAmerican.com. 9 Jan. 2003. <http://www.sciam.com/print_vers ion.cfm?articleID=0007C5B6-7152-1DF6-9733809EC588EEDF>.

Woodroof, J.G. 1986. History and growth of fruit processing, p. 1-24. In: J.G. Woodroof and B.S. Luh (eds.).Commercial fruit processing. 2nd ed. AVI, Westport, Conn. 